\title{
Metode Pembelajaran dalam Meningkatkan Minat Belajar Pendidikan Agama Islam di Sekolah Menengah Pertama
}

\author{
Sholehatin1, Wirdati ${ }^{2}$ \\ sholehatin180698@gmail.com ${ }^{1}$, wirdati@fis.unp.ac.id ${ }^{2}$ \\ Universitas Negeri Padang ${ }^{1,2}$
}

\begin{tabular}{|c|c|}
\hline ARTICLE INFO & \multirow{15}{*}{$\begin{array}{l}\text { ABSTRACT } \\
\text { Penelitian ini dilakukan untuk mengetahui } \\
\text { metode pembelajaran yang digunakan guru dalam } \\
\text { meningkatkan minat belajar siswa pada mata } \\
\text { pelajaran pendidikan agama Islam. Penelitian ini } \\
\text { menggunakan metode kualitatif. Lokasi penelitian ini } \\
\text { di Sekolah Menengah Pertama Negeri } 1 \text { Tiumang, } \\
\text { Kabupaten Dharmasraya. Data diperoleh melalui } \\
\text { wawancara, observasi, dan dokumentasi. Data } \\
\text { dianalisis melalui tiga tahap yaitu reduksi data, } \\
\text { penyajian data, dan penarikan kesimpulan. Temuan } \\
\text { penelitian ini adalah metode pembelajaran yang } \\
\text { digunakan guru dalam meningkatkan minat belajar } \\
\text { peserta didik yang bervariatif. Variasi metode yaitu } \\
\text { metode ceramah, diskusi, tanya jawab, pemberian } \\
\text { tugas, demonstrasi, keteladanan, nasihat, penghargaan } \\
\text { (reward) dan hukuman (punishment), dan } \\
\text { pembelajaran di luar kelas. Metode pembelajaran yang } \\
\text { bervariatif ini diharapkan dapat meningkatkan minat } \\
\text { belajar peserta didik pada mata pelajaran pendidikan } \\
\text { agama Islam. }\end{array}$} \\
\hline Article history: & \\
\hline Received 5 Agustus 2021 & \\
\hline Revised 24 Agustus 2021 & \\
\hline Accepte & \\
\hline Keywords: & \\
\hline Metode Pembelajaran, & \\
\hline Minat Belajar, & \\
\hline Pendidikan Agama Islam. & \\
\hline Clonflict of Interest: & \\
\hline None & \\
\hline Funding: & \\
\hline None & \\
\hline & \\
\hline & \\
\hline
\end{tabular}

Corresponding Author: Sholehatin, Department Islamic Education Fakulty of Social Science Universitas Negeri Padang, Indonesia, Email: sholehatin180698@gmail.com Phone No.: +62822-84544646

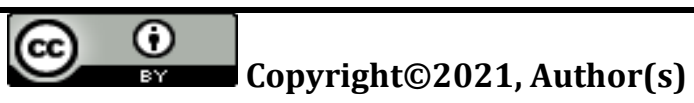

\section{Pendahuluan}

Minat belajar sangat menentukan keberhasilan belajar peserta didik di sekolah (Purwati, 2010). Sebagaimana juga disebutkan Susanto (2013) minat belajar memegang peranan penting dalam menunjang tercapainya efektivitas proses belajar 
mengajar, karena minat belajar akan mempengaruhi hasil belajar peserta didik. Minat belajar peserta didik akan muncul jika ada pengaruh dari luar yaitu guru. Faktor yang mempengaruhi minat belajar siswa adalah guru (Indra, 2017). Sedangkan wildanum (2019) menyebutkan bahwa minat belajar dipengaruhi metode dan media pembelajaran yang digunakan guru. Jadi guru disini memiliki peranan penting dalam menumbuhkan minat belajar peserta didik.

Minat belajar peserta didik dapat diukur melalui beberapa indikator minat yaitu; adanya perasaan senang, perhatian, partisipasi, keinginan dan kesadaran dalam belajar (Herlina, 2010). Dengan adanya beberapa indikator minat tersebut maka guru dituntut untuk menumbuhkan beberapa indikator pada diri peserta didik agar mereka berminat dalam belajar. Guru merupakan bagian terpenting dalam proses belajar mengajar, baik dalam pendidikan formal, informal, atau non formal (Hamdayama, 2016). Guru pendidikan agama Islam adalah tenaga pendidik/ pengajar profesional yang mendidik peserta didiknya berdasarkan pokok-pokok dan kajian yang meliputi ayat-ayat al-Qur'an, hadits, dan akidah, serta ajaran akhlak (Siregar, 2019). Seorang guru pendidikan agama Islam harus memiliki kompetensi yang harus dikuasai yaitu perencanaan, pengelolaan, dan evaluasi (Hamdayama, 2016).

Pentingnya peranan guru dalam proses pembelajaran ditunjukan dengan banyaknya peran guru. Peranan tersebut diantaranya sebagai berikut; demonstrator, pengelola kelas, mediator/ fasilitator, dan evaluator (Hamdayama, 2016). Peran seorang guru lainnya adalah sebagai pembimbing, penyedia lingkungan, model, perencana, dan inovator (Zein, 2016). Alif (2020) juga menyebutkan peran guru dalam belajar yaitu guru sebagai pendidik/ pengajar, mediator, fasilitator, model, pembimbing, evaluator dan motivator. Peran guru sebagai motivator adalah guru harus dapat mendorong dan membangun semangat peserta didik untuk belajar. Motivasi belajar memiliki keterkaitan dengan minat dan prestasi belajar (Alif, 2020). Oleh karena itu, guru harus mampu menumbuhkan minat belajar peserta didik secara lebih kreatif. Salah satu cara adalah guru harus mengetahui strategi dan metode pembelajaran yang tepat untuk diterapkan. Salah satu upaya yang dapat dilakukan guru dalam meningkatkan minat belajar pendidikan agama Islam yaitu dengan memahami kedudukan metode sebagai komponen yang menentukan keberhasilan kegiatan belajar mengajar (Zain, 2010). Berdasarkan grandtour peneliti di SMP Negeri 1 Tiumang minat belajar peserta didik pada mata pelajaran agama Islam masih perlu dikembangkan. Maka guru pendidikan agama Islam sebagai pendidik berupaya untuk meningkatkan minat belajar peserta didik. Adapun upaya yang dapat dilakukan untuk meningkatkan minat belajar peserta didik yaitu : 1) memulai menggunakan cerita yang berkaitan dengan materi, 2) memberikan perhatian khusus kepada peserta didik yang mulai jenuh, 3) menggunakan media pembelajaran, 4) menggunakan berbagai metode pembelajaran, 5) melaksanakan pembelajaran di luar kelas, seperti di mesjid sekolah, 6) menerapkan reward and punishment (Pratanti, 2018). 
Sholehatin dan Wirdati: Metode Pembelajaran dalam Meningkatkan Minat Belajar Pendidikan...

Tulisan ini ingin menggambarkan lebih lanjut tentang metode pembelajaran yang digunakan guru dalam meningkatkan minat belajar peserta didik pada mata pelajaran pendidikan agama Islam di SMP Negeri 1 Tiumang.

\section{Tinjauan Pustaka}

\section{A. Metode Pembelajaran}

Metode merupakan cara yang digunakan untuk mengimplementasikan rencana yang telah disusun dalam kegiatan nyata agar tujuan yang telah disusun tercapai secara optimal (Sanjaya, 2006). Metode juga merupakan cara yang digunakan guru untuk menyampaikan materi pelajaran kepada peserta didik untuk mencapai tujuan pembelajaran (Sholihatin, 2014). Metode dapat diartikan sebagai suatu cara atau teknik yang digunakan oleh guru dalam menyampaikan materi pelajaran, agar penyampaian materi tersebut dapat diterima oleh peserta didik dengan baik, sesuai dengan apa yang diharapkan guru dan sekolah dalam proses belajar mengajar (Hawi, 2013).

Dari beberapa pendapat di atas dapat disimpulkan bahwa metode adalah suatu cara atau teknik yang digunakan oleh guru dalam menyampaikan materi pembelajaran untuk mencapai tujuan pembelajaran. Selain itu, dalam menerapkan metode pembelajaran guru harus memahami kedudukan metode sebagai salah satu komponen untuk mencapai keberhasilan proses belajar mengajar (Zain, 2010). Menerapkan metode yang bervariasi akan memberikan rangsangan kepada peserta didik untuk berminat dan termotivasi dalam belajar (Maesaroh 2013). Minat belajar akan muncul apabila guru dapat menerapkan metode belajar yang sesuai dengan karakter peserta didik, situasi dan materi pelajaran (Hawi, 2013).

Kedudukan metode dalam pembelajaran menurut Zain (2010) yaitu; 1) Metode sebagai alat motivasi ekstrinsik. Motivasi bisa berasal dari dalam diri seseorang, dan dari luar diri seseorang yang dikenal sebagai motivasi ekstrinsik. Salah satu komponen yang dapat memberikan motivasi belajar yang bersifat ekstrinsik yaitu guru dengan menggunakan metode pembelajaran yang tepat (Tambak, 2014). Metode pembelajaran dapat menjadi perangsang dari luar yang dapat membangkitkan gairah belajar peserta didik; 2) Metode sebagai strategi pembelajaran. Melalui penggunaan metode pembelajaran yang tepat, maka secara otomatis guru dapat mempersiapkan strategi pembelajaran (Tambak, 2014). Guru pendidikan agama Islam merancang strategi agar tujuan pembelajaran tersampaikan dengan maksimal; 3) Metode sebagai alat untuk mencapai tujuan. Penggunaan sebuah metode pembelajaran pada mata pelajaran pendidikan agama Islam mempermudah seorang guru agama dalam mengajar (Tambak, 2014). Dengan metode juga dapat membantu guru dalam menyampaikan materi, dan membantu siswa memahami materi sehingga tujuan pembelajaran tercapai dengan maksimal.

\section{B. Macam-macam Metode pembelajaran}


Ada beberapa macam metode pembelajaran yang dapat digunakan guru dalam meningkatkan minat belajar yaitu:

1) Metode Ceramah

Metode ceramah juga dapat dikatakan sebagai metode pembelajaran yang berpusat pada guru. Metode ceramah adalah penerangan dan penyampaian secara lisan yang dilakukan guru kepada peserta didik (Ramayulis 2005). Metode pembelajaran yang berpusat pada guru ini merupakan cara pembelajaran yang menempatkan guru sebagai satu-satunya informasi, pelatih, dan pengarah dalam proses belajar mengajar (Hawi, 2013). Dalam metode ceramah ini peserta didik duduk, menonton, mendengarkan dan percaya bahwa apa yang dikatakan guru adalah benar, peserta didik juga mengutip gambaran umum dari ceramah yang disampaikan oleh guru sebaik mungkin dan menghafalnya tanpa ada tindak lanjut dari guru (Daradjat, 2011). Langkah-langkah yang dapat dilakukan dalam penerapan metode ceramah yaitu; menyampaikan tujuan pembelajaran, menentukan pokokpokok materi yang akan diceramahi, mempersiapkan alat pelajaran, mengelola perhatian siswa, penyampaian materi pelajaran, memberikan kesimpulan, dan guru melakukan evaluasi (Syahraini Tambak, 2014).

\section{2) Metode Diskusi}

Metode diskusi merupakan kegiatan bertukar informasi, pendapat, dan unsur pengalaman secara teratur (Hamdayama, 2016). Metode diskusi juga berarti metode penyajian pelajaran di mana peserta didik dihadapkan pada suatu masalah yang dapat berupa pertanyaan-pertanyaan problematik atau pertanyaan-pertanyaan untuk didiskusikan dan dipecahkan bersama (Zain, 2010). Sehingga dapat dikatakan bahwa metode diskusi ini merupakan metode yang memberikan kesempatan kepada peserta didik untuk mengeluarkan dan mengembangkan ide-idenya. Menurut Zain (2010), menyebutkan langkah-langkah dalam pelaksanaan diskusi yaitu; pertama, merumuskan masalah secara jelas; kedua, guru membagi siswa dalam beberapa kelompok; ketiga, siswa diberikan pengawasan atau bimbingan; keempat, guru memberikan dorongan sehingga anak aktif; kelima, materi diskusi dikerjakan oleh tiap anggota kelompok tidak individu; dan keenam, setiap siswa mencatat hasil diskusi dan menyampaikan di depan kelas.

\section{3) Metode Eksperimen}

Metode eksperimen (percobaan) adalah cara penyajian pelajaran, di mana peserta didik bersikap sebagai penguji dengan mengalami dan membuktikan sesuatu yang telah dipelajarinya (Zain, 2010). Metode eksperimen ialah seorang peserta didik yang melakukan uji coba atau percobaan yang setiap proses dan hasil percobaan diamati oleh peserta didik (Ramayulis, 2005). Metode ini biasanya dilakukan dalam suatu pelajaran seperti ilmu alam, kimia, dan sejenisnya, biasanya pada ilmu-ilmu alam dalam penelitiannya menggunakan metode-metode yang objektif, baik yang 
Sholehatin dan Wirdati: Metode Pembelajaran dalam Meningkatkan Minat Belajar Pendidikan...

dilakukan di dalam/di luar kelas maupun di laboratorium (Daradjat, 2011). Dalam pendidikan agama Islam metode eksperimen ini juga digunakan dalam mengajarkan masalah praktek ibadah. Contohnya dalam eksperimen perkembangan tumbuhtumbuhan seperti menanam pohon anggur dan cabai, tanaman tersebut sama-sama tumbuh dan mendapatkan nutrisi yang sama, namun saat berbuah tanaman tersebut memiliki rasa yang berbeda, anggur akan menghasilkan buah yang manis. Demikianlah Allah SWT telah mengatur semua itu, tak ada aturan-aturan seperti itu, selain datangnya dari Allah SWT.

\section{4) Metode Demonstrasi}

Metode demonstrasi merupakan suatu metode penyajian pembelajaran dengan memperagakan atau mendemonstrasikan kepada peserta didik suatu proses, situasi, atau objek tertentu yang sedang dipelajari, baik yang aktual maupun tiruan disertai pula dengan penjelasan lisan (Zain, 2010). Demonstrasi juga dapat diartikan sebagai metode pengajaran yang menggunakan alat peraga untuk menjelaskan suatu pengertian atau menunjukkan cara melakukan sesuatu kepada peserta didik (Daradjat, 2011). Metode ini memiliki kelebihan yaitu dapat membuat pelajaran lebih jelas, dan memudahkan peserta didik memahami pelajaran (Zain, 2010). Langkahlangkah yang dapat dilakukan guru dalam menerapkan metode ini adalah guru menyampaikan tujuan pembelajaran yang ingin dicapai, guru menjelaskan gambaran secara ringkas materi yang akan diajarkan, menyiapkan alat dan bahan yang diperlukan, mengutus perwakilan peserta didik untuk mencontohkan atau mempraktekkan di depan kelas, peserta didik yang lain memperhatikan, menganalisis dan guru memberikan kesimpulan (Slameto, 2016).

\section{5) Metode Pemberian Tugas}

Metode ini merupakan metode penyajian materi dengan guru memberikan tugas-tugas tertentu agar peserta didik melaksanakan kegiatan pengajaran, dan proses penugasan ini dapat dilakukan di sekolah, laboratorium, perpustakaan, di rumah atau di mana saja dan dapat diberikan secara individu atau kelompok (Zain, 2010). Metode ini berpusat pada peserta didik dan mereka diberikan berbagai masalah sehingga mereka memecahkan, menanggapi, dan memikirkan masalah tersebut (Daradjat, 2011). Penerapan metode ini dapat menumbuhkan tanggung jawab dan disiplin peserta didik, merangsang dan mengembangkan kreativitas peserta didik (Zain, 2010).

\section{6) Metode Sosiodrama}

Sosiodrama merupakan suatu metode pembelajaran bermain peran yang dilakukan oleh sekelompok orang untuk memecahkan masalah yang berkaitan dengan fenomena sosial yang menyangkut hubungan antar manusia seperti 
kenakalan remaja, narkoba, dan permasalahan sosial lainnya (Sanjaya, 2006). Metode sosiodrama ini dapat diimplementasikan dalam bidang studi agama, khususnya bidang sejarah Islam. Misalnya tentang bagaimana sikap para sahabat Nabi, termasuk Umar bin Khattab, tidak akan pernah masuk Islam. Pada awalnya, dia adalah orang yang sangat menentang Islam, dan setelah mendengar ayat-ayat Al-Qur'an dia masuk Islam. Perubahan sikap Umar bin Khattab juga dapat diperankan dalam drama yang diperankan oleh peserta didik, agar makna yang tersirat dalam cerita tersebut dapat dipahami oleh peserta didik (Daradjat, 2011).

\section{7) Metode Latihan (Drill)}

Metode latihan merupakan strategi mengajar yang digunakan guru untuk menanamkan rutinitas yang bermanfaat, dan mengikuti kebiasaan tersebut, sehingga peserta didik dapat memperoleh kesiapan, kepastian, peluang, dan kemampuan (Zain, 2010). Metode drill dimaksudkan untuk memberikan ketangkasan dan keterampilan latihan terhadap apa yang sudah dipelajari oleh peserta didik (Ramayulis, 2005). Metode ini memberikan kebaikan yaitu akan memberikan kepercayaan diri peserta didik, dan memberikan kemampuan kemahiran terhadap sesuatu, serta lebih memudahkan guru dalam mengontrol peserta didik dan dapat membedakan peserta didik yang disiplin atau pun tidak (Ramayulis, 2005).

\section{8) Metode Tanya Jawab}

Metode ini merupakan suatu metode penyajian pelajaran dalam bentuk pertanyaan yang harus dijawab, pertanyaan tersebut dapat dari guru kepada siswa, atau dari siswa kepada guru (Zain, 2010). Metode tanya jawab adalah metode yang cara mengajarnya guru memberikan beberapa pertanyaan kepada peserta didik mengenai materi yang telah dipelajari, dengan mengharapkan jawaban yang tepat dan sesuai fakta dari peserta didik (Ramayulis, 2005). Metode ini bertujuan untuk menyempurnakan metode ceramah yang telah diterapkan oleh guru dalam meperoleh seberapa pemahaman siswa pada materi yang telah dijelaskan. Metode ini dapat menarik dan memusatkan perhatian siswa, merangsang daya pikir peserta didik, dan menumbuhkan keberanian peserta didik dalam menyampaikan pendapatnya.

\section{9) Metode Proyek}

Metode ini merupakan metode pengajaran yang memberikan kesempatan siswa untuk menggunakan satuan kehidupan sehari-hari sebagai bahan pembelajaran, dan metode ini bertujuan agar siswa tertarik untuk belajar (Hamdayama, 2016). Metode ini berfokus pada peserta didik, dan guru ini berperan sebagai pembimbing. Tujuan metode ini adalah untuk melatih peserta didik agar berpikir secara ilmiah, logis dan sistematis (Daradjat, 2011). Contohnya guru memberikan suatu permasalahan yang harus diselesaikan oleh peserta didik. Seperti 
Sholehatin dan Wirdati: Metode Pembelajaran dalam Meningkatkan Minat Belajar Pendidikan...

suatu pohon yang tumbuh, namun ia mati maka guru bertanya apa yang meyebabkan pohon tersebut mati, maka peserta didik akan mencari dan meyelesaikan permasalahan tersebut dengan mengkaji dengan bahan-bahan dan sumber-sumber yang dapat membantunya.

\section{0)Metode Keteladanan}

Menjadi suri tauladan yang baik tentunya akan diikuti oleh pikiran dan perilaku sekaligus. Seorang anak atau peserta didik akan menjadikan seseorang sebagai pembimbing atau panutan bagi dirinya. Biasanya seseorang yang menjadi panutan adalah orang yang paling dekat dengannya, misalnya orang tua menjadi panutan bagi anaknya, dan seorang guru yang menjadi panutan bagi peserta didiknya. Jika seorang guru ingin peserta didiknya memiliki akhlak yang mulia, tentunya guru harus memberikan contoh yang baik pula. Karena meniru adalah cara yang baik dan efektif untuk dalam mendidik anak kecil, dan orang dewasa.

\section{1)Metode Dialog (Nasihat)}

Dalam metode ini, guru diharapkan menjadi teman, bukan sebagai guru. Karena guru tidak hanya memberikan Ilmu tetapi juga bertanggung jawab terhadap akhlak anak didiknya. Sehingga metode ini sangat efektif untuk mengetahui apa yang sedang dialami peserta didik, dan dapat memberikan jalan keluar dari permasalahan tersebut.

\section{2) Metode Penghargaan}

Secara umum, penghargaan dapat terbagi dua, yaitu penghargaan non verbal dan verbal. Penghargaan tersebut dapat menumbuhkan ketertarikan atau minat peserta didik dalam belajar (Hawi, 2013). Penghargaan nonverbal dapat berupa hadiah yang diberikan guru kepada peserta didik yang melakukan hal-hal keagamaan seperti puasa, menyelesaikan Al-Qur'an tiga puluh juz, maka guru memberikan motivasi atau hadiah/reward. Penghargaan tidak hanya berupa barang tetapi dapat berupa pujian, perilaku guru terhadap peserta didik seperti perhatian, kasih sayang dan lain-lain.

\section{3)Metode Hukuman}

Dalam metode ini hukuman yang diberikan bukan lah hukuman yang berupa dipenjarakan atau hukuman potong tangan. Hukuman yang dimaksud ialah pemberian sanksi yang mendidik bagi peserta didik yang ribut atau membuat onar di dalam kelas selama proses pembelajaran (Hawi 2013). Metode hukuman ini diberikan agar peserta didik yang ribut atau tidak berminat dalam belajar jerah, dan diharapkan peserta didik dapat berminat dan fokus kembali dalam belajar. 


\section{Minat Belajar}

Minat belajar terdiri dari 2 kata yaitu minat dan belajar. Kedua kata tersebut memiliki arti yang berbeda sehingga penulis akan mendefenisikan masing-masing kata tersebut. Kata minat dalam Kamus Bahasa Indonesia Sugono (2008) berarti kecenderungan yang tinggi terhadap sesuatu; perhatian; kesukaan. Menurut Rahmayanti (2016) minat adalah faktor yang berasal dari dalam diri manusia dan berfungsi sebagai pendorong melakukan sesuatu yang memberikan individu kearah perhatian, kesenangan, keinginan dan pengalaman secara sadar, sedangkan aspek perilaku afektif minat memiliki ciri-ciri arah, intensitas, dan sasaran. Minat juga merupakan kecendrungan untuk melakukan sesuatu kegiatan sebagai dorongan untuk mencapai suatu tujuan (Nasution, 2019).

Belajar juga merupakan proses mengubah perilaku menjadi lebih baik melalui pengalaman dan latihan pendidikan (Hasipah, 2018). Sementara itu, Nasution (2019) menyatakan bahwa belajar merupakan suatu proses bagi siswa untuk membangun ide atau pemahamannya, sehingga kegiatan pembelajaran harus memberikan kesempatan pada siswa untuk melakukannya dengan lancar dan termotivasi. Febriyanti dan Seruni (2015) menyatakan bahwa minat belajar adalah keinginan siswa untuk belajar sehingga ketika siswa diberikan pelajaran mereka akan memperhatikan dan secara aktif berusaha mengetahui dan memahami pelajaran tersebut. Minat belajar juga merupakan suatu kecendrungan siswa untuk memperhatikan suatu kegiatan untuk perubahan perilaku, dan merupakan suatu keadaan dimana seseorang merasa suka dan tertarik pada suatu hal atau kegiatan tanpa ada yang menyuruh (Hasipah, 2018).

Dari beberapa pendapat di atas dapat dikemukakan bahwa minat belajar adalah suatu usaha sadar yang mendorong peserta didik untuk tertarik melakukan sesuatu dengan senang hati atau dengan keinginannya untuk berusaha mengetahui dan mempelajari pelajaran yang diinginkan atau diminatinya.

\section{Karakteristik Peserta Didik Berminat dalam Belajar}

Dalam pembelajaran, jika peserta didik memiliki minat belajar akan terlihat dari sikap peserta didik di dalam kelas. Ada beberapa karakteristik peserta didik yang berminat menurut Abdurrahman (dalam Hasipah, 2018) sebagai berikut: memiliki sikap; kemauan; ketertarikan; dorongan; ketekunan; dan perhatian dalam belajar. Peserta didik yang berminat memiliki ciri-ciri sebagai berikut: memiliki ketertarikan untuk memperhatikan dan mengingat apa yang dipelajari, adanya rasa suka dan senang terhadap pelajaran, memperoleh rasa bangga dan puas terhadap sesuatu yang diminati, yaitu dengan meliliki rasa keterkaitan pada terhadap suatu kegiatan yang 
Sholehatin dan Wirdati: Metode Pembelajaran dalam Meningkatkan Minat Belajar Pendidikan...

diminati, lebih menyukai satu hal yang menarik baginya daripada yang lainnya, dan aktif dalam kegiatan pembelajaran (Slameto, 2010).

Berdasarkan beberapa pendapat di atas, dapat disimpulkan bahwa siswa yang berminat dalam belajar akan terlihat senang mengikuti pembelajaran, dan memiliki semangat untuk mengikuti proses pembelajaran, dan siswa akan terlihat fokus mengikuti pembelajaran.

\section{E. Faktor-Faktor yang Mempengaruhi Minat Belajar}

Beberapa faktor yang mempengaruhi belajar belajar menurut Wahab (2016) yaitu :

1) Faktor Internal

a. Faktor fiologis, yang termasuk faktor fisiologis adalah kesehatan. Kondisi fisik sangat mempengaruhi aktivitas belajar seseorang. Kondisi fisik yang sehat akan memberikan pengaruh positif terhadap aktivitas belajar individu.

b. Faktor psikologis

Ada beberapa faktor psikologis yaitu :

(1)Kecerdasan/inteligensi siswa, keserdasan didefenisikan sebagai kemampuan psikofisik untuk bereaksi terhadap rangsangan atau beradaptasi dengan lingkungan dengan cara yang benar.

(2)Motivasi, merupakan salah satu faktor yang mempengaruhi efektifitas kegiatan belajar peserta didik. hal tersebut merupakan motivasi yang mendorong peserta didik untuk mengikuti proses pembelajaran.

(3)Minat, merupakan kecenderungan dan kegairahan yang tinggi atau keinginan yang besar terhadap sesuatu.

(4)Sikap, adalah gejala internal yang memiliki dimensi afektif berupa kecendrungan untuk bereaksi atau merespon dengan cara yang relatif tetap terhadap objek, orang, peristiwa, dan sebagainya.

(5)Bakat (aptitude), merupakan potensi kemampuan yang dimiliki seseorang untuk mencapai kesuksesan di masa depan

2) Faktor Eksternal

a. Lingkungan social, yang temasuk dalam faktor tersebut ialah faktor lingkungan sosial masyarakat, lingkungan sosial keluarga, dan lingkungan sosial sekolah.

b. Lingkungan nonsosial, merupakan faktor yang mempengaruhi peserta didik dimana faktor nonsosial tersebut adalah kondisi udara dan cuaca. Jika alam mendukung proses belajar akan baik, tetapi sebaliknya jika kondisi alam tidak mendukung proses belajar peserta didik akan terhambat. Selain kondisi udara dan cuaca, faktor nonsosial lainnya yaitu sarana dan prasarana seperti gedung sekolah, alat-alat belajar, fasilitas belajar, lapangan olahraga, kurikulum sekolah, peraturan sekolah, buku panduan, silabus, dan sebagainya. 


\section{Metodologi}

Penelitian ini menggunakan pendekatan kualitatif. Pendekatan ini sangat berguna dalam memahami fenomena-fenomena sosial dari perspektif partisipan (Maleong, 2011). Partisipan dalam hal ini adalah informan yang diwawancarai dan diamati baik aktifitas, pendapat, pemikiran, persepsi mereka. Pengambilan informan menggunakan purposive sampling, pemilihan informan dengan teknik di atas sangat tepat karena menurut Sugiyono (2017) dalam penelitian kualitatif penulis diperbolehkan memilih informan sesuai dengan pertimbangan dan keperluan data yang akan dicari. Teknik analisis data menggunakan tiga tahap yaitu reduksi data, penyajian data dan kesimpulan (Saleh, 2017).

\section{Hasil dan Pembahasan}

Metode pembelajaran yang digunakan guru dalam meningkatkan minat belajar peserta didik pada mata pelajaran Pendidikan Agama Islam di SMP Negeri 1 Tiumang.

Keberhasilan dalam belajar itu tergantung pada cara mengajar dan penerapan metode yang digunakan oleh guru dalam pembelajaran (Tambak, 2014). Sebagaimana yang disampaikan oleh Nurliana sebagai guru agama, mengatakan:"Metode pelajaran merupakan cara yang digunakan dalam mengajar untuk menyampaikan materi sehingga dapat dipahami oleh siswa dan tujuan dari pembelajaran dapat tercapai" (Wawancara peneliti, 06 April 2021).

Dari uraian di atas tergambar bahwa guru agama Islam, mengerti dan memahami tentang betapa pentingnya penggunaan metode dalam suatu pembelajaran. Dengan memahami hal tersebut, kegiatan belajar mengajar akan semakin terarah. Jadi yang pertama kali yang harus dilakukan seorang guru yaitu memahami terlebih dahulu tentang pengertian metode pembelajaran dan bagaimana menentukan metode pembelajaran yang sesuai. Guru pendidikan agama Islam menyebutkan dalam wawancara bahwa; “..dalam memilih metode itu membutuhkan banyak petimbangan, karena tidak dapat ditentukan asal-asalan, namun harus sesuai dengan tujuan pembelajaran dan materi pelajaran tersebut. Agar tujuan pelajaran tersebut dapat tercapai apabila metode yang digunakan sesuai akan membuat siswa senang, aktif, dan mudah memahami pelajaran..." (Wawancara Peneliti, 06 April 2021).

Pemilihan metode pembelajaran merupakan keharusan yang dilakukan oleh guru agar materi yang disampaikan mudah diterima, dan dapat menumbuhkan keaktifan serta minat peserta didik dalam belajar PAI. sebagaimana dalam Al-Qur'an surah An-Nahl,16: 125.

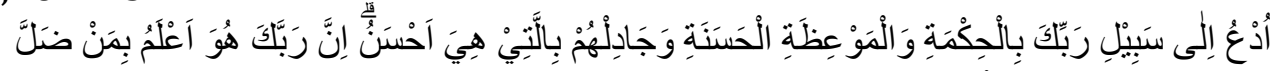

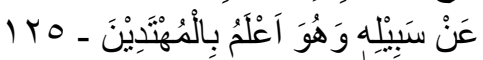

"Serulah (manusia) kepada jalan Tuhanmu dengan hikmah dan pengajaran yang baik, dan berdebatlah dengan mereka dengan cara yang baik. Sesungguhnya Tuhanmu, 
Sholehatin dan Wirdati: Metode Pembelajaran dalam Meningkatkan Minat Belajar Pendidikan...

Dialah yang lebih mengetahui siapa yang sesat dari jalan-Nya dan Dialah yang lebih mengetahui siapa yang mendapat petunjuk" ( Q.s An-Nahl,16:125).

Ayat di atas merupakan dasar yang dapat digunakan dalam mengkaji tentang metode pembelajaran. Ayat tersebut memiliki makna perintah menyeru dan mengajak. Maka hal tersebut membutuhkan cara atau strategi, dan cara itu dapat disebut sebagai metode pembelajaran. Berdasarkan ayat di atas terdapat teknikteknik penting dalam menerapkan suatu metode, yaitu:

a. Hikmah, yaitu manfaat yang terkandung dari pembelajaran tersebut.

b. Al-mau'izah al-hasanah, yaitu berisi pesan-pesan yang disampaikan yang mengandung nasehat. dan

c. Jadil hum bi al-lati hiya ahsan.

Dapat disimpulkan bahwa dalam menentukan metode pembelajaran yang akan digunakan harus diperlukan pertimbangan seperti; tujuan pembelajaran, materi yang akan diajarkan, dan karakter peserta didik itu sendiri. Guru agama Islam menyebutkan bahwa:"Metode yang ibu gunakan dalam mengajar bervariasi agar dapat menumbuhkan minat belajar peserta didik. Dalam mengajar ibu juga tidak hanya menggunakan satu metode saja, tapi mengkombinasikan beberapa metode seperti metode ceramah, diskusi, penugasan, dan praktek" (Wawancara Penelitian, 06 April 2021).

Dari data di atas terlihat upaya yang dilakukan guru untuk meningkatkan minat belajar peserta didik dengan menerapkan metode belajar yang bervariasi dan kreatif. Guru juga melakukan kombinasi beberapa metode pembelajaran agar peserta didik tertarik, berminat dan mudah memahami materi yang diberikan.

Adapun upaya lain yang dapat dilakukan untuk meningkatkan minat belajar selain penerapan metode belajar yang bervariatif. Variasi metode pembelajaran yang digunakan guru pendidikan agama Islam untuk meningkatkan minat belajar peserta didik, sebagai berikut:

\section{1) Metode Ceramah}

Metode ceramah merupakan metode pembelajaran yang berpusat kepada guru yang cara pembelajarannya menempatkan guru sebagai sumber informasi, pembina dan pengarah dalam proses belajar mengajar (Hawi, 2013).

Tabel 4.1 Metode Ceramah

\begin{tabular}{|c|c|c|}
\hline No. & Informan & Petikan Wawancara \\
\hline 1. & $\begin{array}{c}\text { Guru } \\
\text { Agama }\end{array}$ & $\begin{array}{l}\text { Metode pembelajaran yang digunakan dalam mengajar yaitu } \\
\text { metode ceramah...ibu menjelaskan materi secara lisan seperti } \\
\text { menjelaskan manfaat makanan halal dan haram, dan } \\
\text { menjelaskan tentang sholat sunnah jama'dan qosar... }\end{array}$ \\
\hline 2. & $\begin{array}{c}\text { Kepala } \\
\text { Sekolah }\end{array}$ & $\begin{array}{l}\text { Metode yang digunakan guru agama yaitu metode } \\
\text {...ceramah...guru memberikan penjelasan seperti dalam } \\
\text { materi sholat sunnah jama' dan qosar sebelum praktek guru } \\
\text { tentu akan menjelaskan secara lisan terlebih dahulu... }\end{array}$ \\
\hline 3. & $\begin{array}{l}\text { Wakil } \\
\text { Kurikulu } \\
\text { m }\end{array}$ & $\begin{array}{l}\text {... Metode yang digunakan guru agama itu ceramah... guru } \\
\text { menjelaskan secara lisan materi yang akan diajarkan dengan } \\
\text { maksud memberikan pemahaman pengertian... }\end{array}$ \\
\hline
\end{tabular}


Berdasarkan dari pernyataan di atas bahwa jelas guru pendidikan agama Islam menggunakan metode ceramah dalam proses pembelajaran. Hal tersebut juga diperkuat dengan observasi yang dilakukan oleh peneliti di kelas VIII. A terlihat guru melakukan proses pembelajaran yang menggunakan metode ceramah pada materi "Mengkonsumsi makanan dan minuman halal dan menjauhi yang haram" (Observasi peneliti, 05 April 2021 ). Penerapan metode ceramah yang dilakukan guru pendidikan agama Islam dalam usaha menumbuhkan minat belajar peserta didik menurut peneliti sudah baik. Karena, terlihat dari hasil observasi yang dilakukan peneliti yaitu guru sebelum memulai pembelajaran ia melakukan pembukaan, mengkondisikan kelas, guru menyampaikan tujuan dari pembelajaran, guru juga melakukan apersepsi atau pengulangan materi yang terdahulu, dan guru bercerita dengan cerita yang memiliki kaitan dengan materi yang akan diajarakan, serta guru menjelaskan materi yang membutuhkan penggunaan metode ceramah, saat menggunakan metode ceramah guru juga menyelipkan dengan penggunaan metode tanya jawab agar dapat membuat peserta didik tidak bosan, selain metode tanya jawab guru juga menyelipkan dengan pemberian tugas. Hal tersebut dilakukan guru agar saat penggunaan metode ceramah peserta didik tidak akan merasa bosan, dan jenuh di dalam kelas (Observasi Peneliti, 05 April 2021). Dari pernyataan di atas dapat peneliti simpulkan bahwa penerapan metode ceramah yang dilakukan guru sudah baik, karena dalam penerapan metode ceramah, guru pendidikan agama Islam juga menggabungkan metode lain dalam mengajar seperti metode tanya jawab dan pemberian tugas, sehingga saat penerapan metode ceramah tidak membuat peserta didik bosan, dan juga dapat meningkatkan minat, daya tarik peserta didik dalam belajar. Jadi pembelajaran tidak terkesan monoton saja. Sebagaimana yang disebutkan Abdul Majid (2013) bahwa guru dalam mengajar harus mampu mengembangkan metode pembelajaran yang digunakan untuk mencapai tujuan pembelajaran.

Penerapan mengkombinasikan metode yang dilakukan guru pendidikan agama Islam tersebut akan mempermudah peserta didik untuk fokus mendengarkan guru menerangkan, dan mempermudah peserta didik memahami materi yang guru sampaikan. Seperti terlihat saat guru menjelaskan materi dengan metode ceramah, guru juga memberikan kesempatan kepada peserta didik untuk bertanya tentang materi yang belum dipahami yang telah dijelaskan oleh guru. Jika tidak ada peserta didik yang bertanya maka guru yang akan memberikan pertanyaan agar peserta didik aktif, fokus, dan mudah memahami materi, serta dengan guru mengajukan pertanyaan tersebut guru akan mengetahui seberapa pemahaman peserta didik terhadap materi yang telah dijelaskan.

\section{2) Metode Diskusi}

Metode diskusi merupakan kegiatan tukar menukar informasi, pendapat, yang tujuannya agar memperoleh informasi, pengertian sesuatu yang jelas dan memperoleh keputusan bersama dalam menyelesaikan suatu masalah (Hamdayama, 2016).

Tabel 4.2 Metode Diskusi

No. Informan Petikan Wawancara


Sholehatin dan Wirdati: Metode Pembelajaran dalam Meningkatkan Minat Belajar Pendidikan...

\begin{tabular}{|c|c|c|}
\hline 1. & $\begin{array}{l}\text { Guru } \\
\text { Agama }\end{array}$ & $\begin{array}{l}\text { Metode pembelajaran yang digunakan dalam mengajar yaitu } \\
\text { metode...diskusi... ibu membagi siswa dalam beberapa } \\
\text { kelompok dan menentukan ketua kelompok dan memberikan } \\
\text { intruksi apa yang akan dilakukan setiap kelompok, dan } \\
\text { setiap kelompok akan mempersentasikan hasil diskusi } \\
\text { mereka... }\end{array}$ \\
\hline 2. & $\begin{array}{l}\text { Kepala } \\
\text { Sekolah }\end{array}$ & $\begin{array}{l}\text { Metode yang digunakan guru agama yaitu metode } \\
\text {...diskusi..pastinya guru akan membagi siswa dalam beberapa } \\
\text { kelompok, menyelesaikan suatu permasalahan, dan membuat } \\
\text { kesimpulan... }\end{array}$ \\
\hline 3. & $\begin{array}{l}\text { Wakil } \\
\text { Kurikulu } \\
\text { m }\end{array}$ & $\begin{array}{l}\text {... Metode yang digunakan guru agama itu...diskusi...guru } \\
\text { membentuk beberapa kelompok, dan setiap kelompok } \\
\text { diharapkan untuk bekerja sama dalam menyelesaikan tugas } \\
\text { yang diberikan.... }\end{array}$ \\
\hline
\end{tabular}

Berdasarkan pernyataan di atas jelas dapat dikatakan bahwa guru memang menerapkan metode diskusi dalam mengajar. Hal tersebut diperkuat dengan observasi yang peneliti lakukan, guru pendidikan agama Islam menerapkan metode diskusi dalam mengajar. Penerapan metode diskusi yang dilakukan guru dalam mengajar mata pelajaran pendidikan agama Islam terlihat saat peneliti melakukan observasi dimana langkah-langkah penerapan metode diskusi yang dilakukan guru yaitu pertama guru menyampaikan tujuan pembelajaran, lalu memberikan arahan kepada peserta didik dengan membagi dalam beberapa kelompok dan masing-masing kelompok terdiri dari 5-6 orang, setelah itu guru pun memberikan arahan apa saja tugas yang harus diselesaikan dalam diskusi, setiap kelompok memiliki ketua kelompok, dan mereka akan mendiskusikan suatu permasalahan dan menyelesaikannya dengan memanfaatkan sumber-sumber yang ada seperti buku paket, dan buku-buku yang ada di perpustakaan, dan setiap kelompok membuat satu catatan hasil dari diskusi mereka, setelah selesai guru pun meminta kepada setiap perwakilan kelompok menyampaikan hasil diskusinya, dan setiap kelompok juga diberikan kesempatan untuk bertanya dan menanggapi hasil dari kelompok lainnya. Setelah selesai guru juga meminta kepada beberapa peserta didik untuk menyimpulkan hasil diskusi yang telah dilakukan, serta guru juga akan menyimpulkan materi tersebut dan memberikan informasi yang belum diperoleh oleh peserta didik saat diskusi.

Berdasarkan dari langkah-langkah yang dilakukan guru pendidikan agama Islam dapat dikatakan sudah baik. Peserta didik juga terlihat aktif dalam belajar diskusi terlihat dari setiap kelompok, setiap anggota kelompok saling berdiskusi untuk menyelesaikan masalah yang diberikan guru, serta peserta didik juga di tuntut untuk aktif dalam menanggapi dan memberikan pertanyaan karena keaktifan itu menjadi point atau nilai tambahan bagi peserta didik. Dengan adanya nilai tambahan itu kan memberikan semangat atau minat peserta didik untuk aktif dalam belajar diskusi.

\section{3) Metode Praktek/Demonstrasi}

Metode demonstrasi merupakan metode yang cara penyajian pembelajarannya dengan memperagakan atau mempertunjukkan kepada peserta didik sehingga mudah dipahami, diikuti dan juga disertai penjelasan secara lisan 
(Zain, 2010). Metode demonstrasi ini biasa digunakan pada materi pendidikan agama Islam seperti sholat, wudhu, tayamum, dan lai-lain.

Tabel 4.3 Metode Demonstrasi

\begin{tabular}{rrl}
\hline No. & Informan & Petikan Wawancara \\
\hline 1. & Guru & $\begin{array}{l}\text { Metode pembelajaran yang digunakan dalam mengajar yaitu } \\
\text { metode...praktek... seperti praktek sholat, wudhu...ibu } \\
\text { melakukan praktek ini di mesjid, atau di dalam kelas... }\end{array}$ \\
\hline 2. & Kepala & Metode yang digunakan guru agama yaitu metode ...metode \\
& Sekolah & praktek seperti praktek sholat sunnah jama'dan qosar... \\
\hline 3. & Wakil & Metode yang digunakan guru agama itu...praktek...seperti \\
& Kurikulu \\
& sholat, wudhu...
\end{tabular}

Berdasarkan hal tersebut dapat disimpulkan bahwa upaya yang dilakukan guru pendidikan agama Islam dalam menumbuhkan minat belajar peserta didik dengan menerapkan metode praktek. Langkah-langkah penerapan metode praktek yang dilakukan guru sebagai berikut: pertama, guru membuka kelas, mengkondisikan kelas, guru menyampaikan tujuan pembelajaran, apersepsi pembelajaran yang lalu dan mengaitkannya dengan materi yang akan diajarkan, setelah itu guru memberikan arahan dalam proses pembelajaran, sebelum menerapkan metode praktek guru memberikan penjelasan-penjelasan atau apa saja tata cara dalam sholat sunnah jama' dan qasar seperti niatnya, dan syarat-syarat yang mana materi tersebut sudah dipelajari pada pertemuan sebelumnya, guru pun menerapkan pembelajaran praktek dengan mengutus beberapa peserta didik untuk kedepan dan mempraktekkan atau memperagakan sholat jama' dan qasar dari bacaan niat dan tata cara sholatnya. Lalu guru menjelaskan kembali atau menguatkan agar peserta didik benar-benar paham dengan tata cara sholat sunnah tersebut (Observasi Peneliti, 08 April 2021).

Langkah-langkah yang dilakukan guru pendidikan agama Islam dalam menerapkan metode praktek tersebut sudah baik, hanya saja harus lebih dikembangkan lagi dan juga guru dapat memanfaatkan media pembelajaran seperti video tentang tata cara sholat yaitu sholat sunnah. Apabila adanya media pembelajaran tersebut akan lebih membuat menarik minat belajar peserta didik dan membuat peserta didik lebih mudah memahami materi yang diajarkan.

\section{4) Metode Tanya Jawab}

Metode tanya jawab merupakan metode yang cara penyajiannya dalam bentuk pertanyaan-pertanyaan yang harus dijawab, pertanyaan tersebut bisa dari guru kepada peserta didik, atau dari peserta didik kepada guru dan peserta didik lainya (Zain, 2010).

Tabel 4.4 Metode Tanya Jawab

\begin{tabular}{rcl}
\hline No. & Informan & Petikan Wawancara \\
\hline 1. & Guru & Metode pembelajaran yang digunakan dalam mengajar yaitu \\
& Agama & metode...tanya Jawab...setelah ibu menyampaikan materi \\
& & tentu ibu akan memberikan pertanyaan atau kesempatan
\end{tabular}


Sholehatin dan Wirdati: Metode Pembelajaran dalam Meningkatkan Minat Belajar Pendidikan...

\begin{tabular}{cl}
\hline & $\begin{array}{l}\text { kepada peserta didik untuk bertanya tentang materi yang } \\
\text { telah diajarkan dengan maksud agar siswa lebih memahami } \\
\text { materi... }\end{array}$ \\
\hline 2. & Wakil \\
Kurikulu & $\begin{array}{l}\text { Metode yang digunakan guru agama itu... tanya jawab... ini } \\
\text { biasanya guru memberikan pertayaan kepada siswa untuk } \\
\text { mengetahui seberapa paham siswa terhadap materi yang } \\
\text { telah diajarkan... }\end{array}$ \\
\hline
\end{tabular}

Observasi yang dilakukan peneliti (05 April 2021) menemukan bahwa guru menerapkan metode tanya jawab saat mengajar. Penerapan metode tanya jawab ini dapat menjadi penyempurna metode ceramah, diskusi yang digunakan guru untuk memperoleh seberapa pemahaman peserta didik terhadap materi yang diajarkan.

\section{5) Metode Pemberian Tugas}

Metode ini berpusat pada peserta didik dan mereka diberikan bermacam masalah agar mereka menyelesaikan, menanggapi permasalahan tersebut (Daradjat, 2011). Metode pemberian tugas ini penyajian bahan dengan guru memberikan tugas tertentu agar peserta didik melakukan kegiatan pembelajaran, dan proses penugasan ini dapat dilaksanakan di sekolah, laboratorium, perpustakaan, di rumah atau di mana saja dan bisa diberikan dalam tugas individu maupun kelompok (Zain, 2010).

Tabel 4.5 Metode Pemberian Tugas

\begin{tabular}{ccl}
\hline No. & Informan & Petikan Wawancara \\
\hline 1. & Guru & $\begin{array}{l}\text { Metode pembelajaran yang digunakan dalam mengajar yaitu } \\
\text { metode... pemberian tugas... dengan maksud agar siswa } \\
\text { membaca materi pelajaran lagi dan lebih memahami materi } \\
\text { yang telah diajarkan... }\end{array}$ \\
\hline 2. & Kepala & $\begin{array}{l}\text { Metode yang digunakan guru agama yaitu metode } \\
\text {...pemeberian tugas atau metode hafalan...agar siswa lebih } \\
\text { memahami materi pelajaran yang diajarkan... }\end{array}$ \\
\hline 3. & Wakil & $\begin{array}{l}\text { Metode yang digunakan guru agama itu.... pemberian } \\
\text { tugas...dengan maksud untuk mengetahui seberapa } \\
\text { kemahaman siswa terhadap materi yang diajarkan oleh } \\
\text { guru... }\end{array}$ \\
& $\mathrm{m}$
\end{tabular}

Berdasarkan observasi yang dilakukan peneliti (05 April 2021) menemukan bahwa guru pendidikan agama Islam menerapkan metode pemberian tugas, penerapan pemberian tugas ini juga dikombinasikan dengan metode pembelajaran lain yaitu seperti dalam penerapan metode ceramah dan diskusi. Penerapan metode pemberian tugas ini diterapkan saat guru menjelaskan materi dengan metode ceramah, setelah menjelaskan guru memberikan tugas kepada peserta didik agar peserta didik juga tidak merasa bosan dengan metode ceramah yang digunakan guru. Jadi penerapan metode pemberian tugas ini diterapkan dengan cara mengkombinasikannya dengan metode pembelajaran lain. Penerapan metode pemberian tugas tersebut bermaksud agar peserta didik dapat lebih memahami materi yang telah diajarkan dan menjadi daya tarik peserta didik untuk belajar menyelesaikan suatu masalah. 


\section{6) Metode Keteladanan}

Menjadi teladan yang baik tentunya akan diikutin oleh pikiran dan tingkahlaku secara bersamaan. Seseorang yang menjadi teladan atau panutan itu biasanya adalah orang terdekatnya, seperti orang tua menjadi panutan bagi anaknya, dan guru menjadi panutan bagi peserta didiknya di sekolah (Hawi, 2013).

Tabel 4.6 Metode Keteladanan

\begin{tabular}{|c|c|c|}
\hline No. & Informan & Petikan Wawancara \\
\hline 1. & $\begin{array}{c}\text { Guru } \\
\text { Agama }\end{array}$ & $\begin{array}{l}\text { Metode pembelajaran yang digunakan dalam mengajar yaitu } \\
\text { metode... keteladanan. Salah satu peran guru yaitu sebagai } \\
\text { model. Guru merupakan panutan peserta didik, maka guru } \\
\text { harus memiliki kepribadian dan menjadi guru yang baik } \\
\text { sehingga memberikan panutan yang baik pula untuk peserta } \\
\text { didiknya... }\end{array}$ \\
\hline 2. & $\begin{array}{l}\text { Kepala } \\
\text { Sekolah }\end{array}$ & $\begin{array}{l}\text {...Guru juga berperan sebagai panutan, yang mana peserta } \\
\text { didik akan menjadikan gurunya sebagai panutan yang akan } \\
\text { diikuti. Maka guru harus memiliki kepribadian yang baik, } \\
\text { dan menjadi panutan yang baik bagi peserta didiknya... }\end{array}$ \\
\hline 3. & $\begin{array}{l}\text { Wakil } \\
\text { Kurikulu } \\
\text { m }\end{array}$ & $\begin{array}{l}\text {...Guru memiliki peran sebagai model atau panutan, guru } \\
\text { menjadi sosok panutan yang dapat ditiru atau diikuti oleh } \\
\text { peserta didik.... }\end{array}$ \\
\hline
\end{tabular}

Dari pernyataan di atas guru merupakan salah satu orang menjadi teladan atau panutan bagi peserta didiknya. Metode keteladanan merupakan metode pendidikan dan pengajaran dengan cara pendidik memberikan contoh teladan yang baik kepada peserta didik agar ditiru dan dilaksanakan (Mustofa, 2019). Apabila guru mampu memberikan keteladanan bagi peserta didiknya baik sebagai pengajar maupun pendidik, maka itu kan menjadi dorongan peserta didik untuk berminat dalam belajar. Keteladanan guru bagi peserta didik ini dalam bentuk ketaatan terhadap aturan dan kedisiplinan dalam menjalankan tugasnya. Jadi dapat dikatakan bahwa apabila guru disiplin dalam menjalankan tugas mengajarnya dan taat terhadap peraturan maka dapat dipastikan bahwa peserta didik akan termotivasi untuk disiplin dan menjalankan aturan sekolah sebagaimana yang di lihat dari guru mereka. Berdasarkan pengamatan bahwa guru pendidikan agama Islam rajin dan sangat disiplin dalam masuk kelas tepat waktu, dengan hal tersebut dapat dijadikan panutan atau teladan bagi peserta didik dapat berminat dan semangat dalam mengikuti proses belajar mengajar dengan baik. Sikap dan tutur kata juga dapat mempengaruhi minat belajar, apabila guru memiliki sikap dan tutur kata yang baik itu akan memberikan gairah dan menumbuhkan minat belajar peserta didik, karena peserta didik akan menyukai dan senang terhadap guru yang memiliki sikap dan tutur kata yang baik. sikap dan tutur kata yang baik itu juga dapat menjadi contoh yang baik untuk ditiru oleh peserta didik. Jadi guru pendidikan agama Islam sudah cukup baik, dalam menjadi teladan dan contoh bagi peserta didik, karena guru pendidikan agama Islam di SMP Negeri 1 Tiumang sangat disiplin dalam masuk kelas, disiplin menjalankan tugasnya sebagai seorang guru, dan memiliki sikap, serta tutur kata yang baik. 
Sholehatin dan Wirdati: Metode Pembelajaran dalam Meningkatkan Minat Belajar Pendidikan...

7) Metode Nasihat

Dalam metode ini guru diharapkan dapat berperan sebagai teman dan sahabat bagi peserta didik bukan hanya menjadi sosok guru saja (Hawi, 2013). Karena guru tidak hanya memberikan ilmunya saja, melainkan guru pendidikan agama Islam juga memiliki tanggung jawab dapat mendidik peserta didik agar memiliki nilai moral dan akhlak yang baik. Metode ini sangat efektif bagi guru untuk mengetahui segala permasalahan yang dihadapi peserta didik dan dapat memberikan solusi dari permasalahan tersebut.

Tabel 4.7 Metode Nasihat

\begin{tabular}{ccl}
\hline No. & Informan & Petikan Wawancara \\
\hline 1. & Guru & Metode pembelajaran yang digunakan dalam mengajar yaitu \\
& Agama & metode...nasihat, dalam penerapan metode nasihat ini guru \\
& meliki peran penting dalam mengontrol dan memahami \\
& masalah yang dihadapi oleh peserta didik, karena guru harus \\
& mampu menjadi sosok teman yang baik sehingga dapat \\
& membantu peserta didiknya yang memiliki masalah yang \\
& dapat mengganggu konsentrasi dalam belajar, sehingga guru \\
& dapat membantu mencari solusi dari permasalahan peserta \\
& didiknya... \\
& Keparu harus mampu memahami kondisi peserta didiknya, \\
& dan apabila terdapat peserta didik yang bermasalah maka \\
& guru harus mampu mengatasinya dan memberikan arahan \\
& atau nasihat kepada peserta didik agar tidak bermasalah \\
& kembali sebagaimana termasuk juga dalam peran guru \\
& sebagai motivator guru harus memberikan motivasi, \\
& dukungan, dan dorongan kepada peserta didik untuk lebih \\
& semangat dan mengatasi permasalahannya termasuk dalam \\
& masalah belajar...
\end{tabular}

Berdasarkan penyataan di atas bahwa guru menerapkan metode nasihat. Guru memiliki multi peran selain mengajar, memberikan ilmunya guru juga mampu berperan sebagai orangtua, teman atau sahabat bagi peserta didiknya. Apabila guru memiliki multi peran seperti itu akan membuat peserta didik untuk bercerita atau menyampaikan permasalahan yang dihadapinya sehingga dapat menemukan solusi melalui gurunya. Metode nasihat ini juga dapat menumbuhkan minat belajar peserta didik. Metode nasihat ini diterapkan guru dalam mengajar dengan menggunakan teknik bercerita, yang mana guru saat mengajar akan memberikan cerita atau kisah yang terjadi dalam kehidupan dan mengaitkan dengan materi yang akan diajarkan. Cerita tersebut mengandung pesan moral. Dari cerita tersebut menyampaikan moral pendidikan yang akan mampu menumbuhkan minat dan gairah peserta didik untuk giat belajar.

Selain penerapan metode pembelajaran yang bervariasi, mengembangkan media pembelajaran dan strategi pembelajaran. peneliti menemukan usaha guru dalam meningkatkan minat belajar agar peserta didik dapat memahami materi yang disampaikan guru yaitu dengan melakukan kuis di akhir pelajaran (Observasi 07 April 2021). Pemberian kuis ini dilakukan guru untuk mengetahui seberapa 
pemahaman peserta didik dalam materi yang telah diajarkan, dengan pemberian kuis ini juga akan mendorong atau memotivasi peserta didik untuk belajar dan mengulang materi pelajaran yang telah diajarkan guru.

Guru pendidikan agama Islam juga melakukan usaha lain seperti pemberian reward dan punishment atau pemberian penilaian kepada peserta didik agar dapat menumbuhkan minat dan semangat belajar.

Tabel 4.9 Reward and Punishment

\begin{tabular}{ccl}
\hline No. & Informan & Petikan Wawancara \\
\hline 1. & Guru & ...yang ibu lakukan yaitu dengan pemberian reward. Reward \\
& Agama & tersebut bisa berupa kata pujian, penghormatan, nilai \\
& tambahan atau bonus nilai. Pemberian reward ini diberikan \\
& & kepada peserta didik yang memiliki prestasi. Pemberian \\
& reward ini dilakukan agar peserta didik memiliki semangat \\
& & dan termotivasi untuk belajar... \\
\hline 2. & Kepala & ... Bagi anak-anak yang memiliki prestasi belajar ia akan \\
& Sekolah & diberikan reward, dan bagi anak yang tidak berprestasi atau \\
& tidak ada kemauan dalam belajar sekali itu akan \\
& mendapatkan punishment yang memotivasi atau sesuai... \\
\hline 3. & Wakil & ...Guru juga memberikan reward dan punishment, reward \\
& berupa pujian atau hadiah yang diberikan oleh guru, \\
& sedangkan punishment maksusnya disini guru memberikan \\
& sanksi yang mendidik siswa untuk lebih fokus dalam belajar... \\
& terkhususnya pada mata pelajaran agama Islam...
\end{tabular}

Guru pendidikan agama Islam melakukan pemberian reward dan punishment agar peserta didik memiliki minat dalam belajar. Berdasarkan pengamatan peneliti, saat belajar diskusi guru akan memberikan nilai tambahan atau point plus bagi peserta didik yang aktif dalam pembelajaran. Tidak hanya belajar diskusi saja, dalam pelajaran lain juga guru memberikan reward kepada peserta didik. Reward yang diberikan guru tidak hanya berupa nilai tambahan tetapi juga dengan memberikan pujian kepada peserta didik, hal tersebut guru berikan agar peserta didik dapat berminat untuk belajar, aktif dan giat dalam belajar. Sedangkan punishment ini diberikan kepada peserta didik yang malas, tidak mengerjakan tugas, datang terlambat, dan yang ribut di dalam kelas. Punishment yang diberikan guru kepada peserta didik berupa punishment yang mendidik namun dapat membuat peserta didik jerah dan tidak akan mengulangi lagi, serta membuat peserta didik lebih rajin kembali dalam belajar. Punishment yang biasa diberikan guru pendidikan agama Islam di SMP N 1 Tiumang seperti tugas tambahan, dan menjelaskan kembali materi yang baru saja dijelaskan oleh guru.

Guru pendidikan agama Islam ibu Nurliana menyebutkan bahwa: "Ibu mengajar siswa biasanya melakukan proses pembelajaran di dalam kelas atau di mushola, namun ibu juga pernah melakukan pembelajaran di luar kelas, seperti di bawah pohon. Belajar di luar kelas ini ibu lakukan agar siswa tidak merasa bosan saat belajar pendidikan agama Islam. Ibu juga sering bercerita dengan mengaitkan hal-hal apa saja yang ada di alam dan mengaitkan dengan nilai moral keagamaan sehingga 
Sholehatin dan Wirdati: Metode Pembelajaran dalam Meningkatkan Minat Belajar Pendidikan...

peserta didik selain akan memahami materi pelajaran ia akan memiliki nilai moral yang baik yang akan diterapkan dalam kehidupan sehari-hari" (Wawancara Peneliti, 06 April 2021). Berdasarkan pernyataan guru pendidikan agama Islam bahwa guru menerapkan pembelajaran di luar kelas. Pembelajaran di luar kelas ini guru lakukan supaya memberikan suasana baru bagi peserta didik, agar peserta didik tidak merasa bosan apabila belajar di dalam ruangan kelas. Jadi dengan pembelajaran kelas ini akan memberikan semangat gairah peserta didik dalam belajar.

Berdasarkan pernyataan di atas dapat ditarik kesimpulan bahwa upaya guru dalam meningkatkan minat belajar peserta didik itu menggunakan metode pembelajaran yang bervariasi. Variasi metode tersebut yaitu; metode ceramah, diskusi, demonstrasi, tanya jawab, pemberian tugas, keteladanan, nasihat, reward and punishment. Dari sembilan metode yang diterapkan guru pendidikan agama Islam, ada empat metode unggulannya yaitu metode ceramah, diskusi, demonstrasi, dan tanya jawab. Adapun teknik belajar yang digunakan guru pendidikan agama Islam yaitu pemberian kuis, dan pembelajaran di luar kelas.

\section{Simpulan}

Berdasarkan paparan di atas dapat disimpulkan bahwa metode pembelajaran yang digunakan guru pendidikan agama Islam di Sekolah Menengah Pertama Negeri 1 Tiumang sudah bervariasi dan guru juga lebih kreatif dalam menerapkan metode dengan menimbangkan beberapa aspek dan mengkombinasikan beberapa metode pembelajaran. Metode yang digunakan guru pendidikan agama Islam ada sembilan yaitu: metode ceramah, diskusi, tanya jawab, pemberian tugas, demonstrasi, keteladanan, nasihat, penghargaan (reward) \& hukuman (punishment), ada empat metode unggulanya yaitu metode ceramah, diskusi, demonstrasi, dan tanya jawab. Teknik pembelajaran yang digunakan guru yaitu pemberian kuis, dan pembelajaran di luar kelas.

\section{Referensi}

Abdul Majid. 2013. Strategi Pembelajaran. Bandung: Remaja Rosdakarya.

Alif, siti Maimunawati dan muhammad. 2020. Peran Guru, Orang Tua, Metode Dan

Media Pembelajaran: Strategi KBM Di Masa Pandemi Covid-19. Serang: 3M Media karya.

Daradjat, Zakiah. 2011. Metodik Khusus Pengajaran Agama Islam. Jakarta: Bumi Aksara.

Febriyanti, Chatarina, and Seruni Seruni. 2015. "Peran Minat Dan Interaksi Siswa

Dengan Guru Dalam Meningkatkan Hasil Belajar Matematika." Formatif: Jurnal

Ilmiah Pendidikan MIPA 4(3):245-54. doi: 10.30998/formatif.v4i3.161.

Hamdayama, Jumanta. 2016. Metodologi Pengajaran. Jakarta: PT Bumi Aksara.

Hasipah, Nur. 2018. "Faktor-Faktor Yang Mempengaruhi Minat Belajar Pendidikan

Agama Islam Pada Siswa Di SMA Negeri 1 Panyabungan Timur."

Hawi, Akmal. 2013. Kompetensi Guru Pendidikan Agama Islam. Jakarta: Rajawali Pers. Herlina. 2010. Minat Belajar. Jakarta: Bumi Aksara.

Maesaroh, Siti. 2013. "PERANAN METODE PEMBELAJARAN TERHADAP MINAT DAN

PRESTASI BELAJAR PENDIDIKAN AGAMA ISLAM.” 1(1):150-68.

Maleong, lexy J. 2011. Metodologi Penelitian Kualitatif. Bandung: PT Remaja

Rosdakarya. 
Mustofa, Ali. 2019. "METODE KETELADANAN PERSPEKTIF PENDIDIKAN ISLAM.” 5. Nasution, Syamsiyah. 2019. "Strategi Guru Dalam Meningkatkan Minat Belajar Siswa Pada Mata Pelajaran Pendidikan Agama Islam Di Sekolah Dasar Negeri 147 Palembang." 07(02):68-79.

Pratanti, Yulia. 2018. "Upaya Guru Dalam Meningkatkan Minat Belajar Ibadah Di SMP Muhammadiyah 7 Surakarta Tahun Pelajaran 2017/2018."

Purwati, Pera. 2010. "PENGARUH PENERAPAN METODE DRILL / LATIHAN TERHADAP MINAT BELAJAR SISWA PADA MATA PELAJARAN FIQIH ( Penelitian Di MTS Attarbiyyah Bayongbong Garut )." Jurnal Pendidikan Universitas Garut 04(1):48-53.

Rahmayanti, Vina. 2016. "Pengaruh Minat Belajar Siswa Dan Persepsi Atas Upaya Guru Dalam Memotivasi Belajar Siswa Terhadap Prestasi Belajar Bahasa Indonesia Siswa SMP Di Depok." SAP (Susunan Artikel Pendidikan) 1(2):206-16. doi: 10.30998/sap.v1i2.1027.

Ramayulis. 2005. Metodologi Pendidikan Agama Islam. Jakarta: Kalam Mulia.

Saleh, Sirajuddin. 2017. Analisis Data Kualitatif. Bandung: Pustaka Ramadhan.

Sanjaya, Wina. 2006. Strategi Pembelajaran Berorientasi Standar Proses Pendidikan. Jakarta: PRENADAMEDIA GROUP.

Sholihatin, Etin. 2014. Strategi Pembelajaran PPKN. Jakarta: Bumi Aksara.

Siregar, Uswatun Hasanah. 2019. “Upaya Guru Pendidikan Agama Islam Dalam Meningkatkan Minat Belajar Siswa Pada Mata Pelajaran Pendidikan Agama Islam Di SMP Negeri 1 Silangkitang Kabupaten Labuhan Batu Selatan." (0298):323706.

Slameto. 2010. Belajar Dan Faktor-Faktor Yang Mempengaruhinya. Jakarta: Rineka Cipta.

Slameto, Fikria Trisnawaty dan. 2016. "Peningkatkan Hasil Belajar Ipa Melalui Penggunaan Metode Demonstrasi Pada Siswa Kelas 4 Sd." 37-44.

Sugiyono. 2017. Metode Penelitian Kuantitatif, Kualitatif, Dan Kombinasi (Mixed Methods). Bandung: ALFABETA.

Sugono, Dendy. 2008. Kamus Bahasa Indonesia. Jakarta: Pusat Busana.

Susanto, Ahmad. 2013. Teori Belajar Dan Pembelajaran Di Sekolah Dasar. Jakarta: PRENADAMEDIA GROUP.

Syahraini Tambak. 2014. "Metode Ceramah: Konsep Dan Aplikasi Dalam Pembelajaran Pendidikan Agama Islam." 21(2):375-401.

Tambak, Syahraini. 2014. Pendidikan Agama Islam; Konsep Metode Pembelajaran PAI. 1st ed. Yogyakarta: Graha Ilmu.

Wahab, Rohmanila. 2016. Psikologi Belajar. Jakarta: Rajawali Pers.

Zain, Syaiful Bahri Djamarah dan Aswan. 2010. Strategi Belajar Mengajar. Jakarta: Rineka Cipta.

Zein, Muh. 2016. "Peran Guru Dalam Pengembangan Pembelajaran.” Jurnal Inspiratif Pendidikan 5(2):274-85. 